\title{
Vascular endothelial primary cilia regulate blood flow-induced EndoMT
}

\author{
B Hierck*, AD Egorova, RE Poelmann \\ From First International Cilia in Development and Disease Scientific Conference (2012) \\ London, UK. 16-18 May 2012
}

Vascular endothelial cells present cilia in response to low and oscillatory flow. Cilia function in transducing local blood flow information into functional responses, like nitric oxide production and initiation of gene expression. In the embryonic heart high flow regime applies to the endocardial cushion area, and the absence of cilia here coincides with the process of endothelial-to-mesenchymal transition (EndoMT). During this transdifferentiation process EC lose their endothelial characteristics, gain a mesenchymal phenotype, and migrate into the cardiac jelly to form the primordia of the cardiac valves. In this study we investigate the role of the primary cilium in further defining the responses of EC to fluid shear stress and in EndoMT. We used embryonic EC from the IFT88Tg737RPW (or Tg737orpk/orpk) mouse, and compared these to ciliated EC under dynamic flow conditions. In vitro, non-ciliated Tg737orpk/orpk EC undergo flowinduced EndoMT which is dependent on downregulation of the transcription factor Klf4. Ciliated wild type (WT) cells retain an epithelial phenotype under these conditions. However, when exposed to higher shear levels WT cells lose their cilia and undergo EndoMT, gaining a phenotype closely resembling that of Tg737orpk/orpk EC under flow. This Tgf $\beta / A l k 5$ dependent transformation is prevented by blocking Tgf $\beta$ signaling, overexpression of Klf4, or rescue of the primary cilium. This study demonstrates the central role of primary cilia in rendering EC prone to shearinduced activation of Tgf / Alk5 signaling and EndoMT, and thereby provides a functional link between primary cilia and flow related endothelial performance.

Published: 16 November 2012

* Correspondence: b.p.hierck@lumc.nl

Leiden University Medical Center, the Netherlands
doi:10.1186/2046-2530-1-S1-P70

Cite this article as: Hierck et al: Vascular endothelial primary cilia regulate blood flow-induced EndoMT. Cilia 2012 1(Suppl 1):P70.
Submit your next manuscript to BioMed Central and take full advantage of:

- Convenient online submission

- Thorough peer review

- No space constraints or color figure charges

- Immediate publication on acceptance

- Inclusion in PubMed, CAS, Scopus and Google Scholar

- Research which is freely available for redistribution
() Biomed Central

\section{() Biomed Central}

